\title{
Opening Science and Innovation: Opportunities for Emerging Economies
}

\author{
Selma Leticia Capinzaiki Ottonicar
}

Ph.D.Candidate, selma.leticia@hotmail.com

Paloma Marín Arraiza

Ph.D. Candidate, pmarrai11@googlemail.com

Sao Paulo State University UNESP, Câmpus de Marília Av. Hygino Muzzi Filho, 737 - Mirante - Marília/SP, Sao Paulo, Brazil

\section{Fabiano Armellini}

Assistant Professor, Department of Mathematics and Industrial Engineering, fabiano.armellini@polymtl.ca

Polytechnique Montréal, 2500 Chemin de Polytechnique, Montréal, QC H3T 1J4, Canada

\begin{abstract}
$\mathrm{O}$ pen innovation allows for partnerships between businesses through knowledge sharing. The mission of open science is to encourage information sharing about academic research. The purpose of this paper is to demonstrate the relevance of open science to open innovation and vice versa, especially in the context of emerging economies. Furthermore, it aims to show the results of the intersection between university and innovative companies. The methodology was based upon a systematic

literature review to understand how researchers have been studying the subject. It also focuses on the relevance of open innovation and open science for business management and information science fields. Therefore, the connection between open science and open innovation is fundamental to encouraging the partnership between businesses and universities. This kind of partnership contributes to the economy of developing countries, so business can become more competitive.
\end{abstract}

eywords: open science; open innovation; emerging economies; systematic literature review; innovation; developing countries; business partnership; university and company; business management; information science
Citation: Ottonicar S.L.C., Arraiza P., Armellini F. (2020) Opening Science and Innovation: Opportunities for Emerging Economies. Foresight and STI Governance, vol. 14, no 4, pp. 95-111. DOI: 10.17323/2500-2597.2020.4.95.111 
$\mathrm{I}$ nformation and communication technology is evolving rapidly and it has become essential in an increasing number of sectors. Both innovation and science have experienced a change in their communication workflows, in their production processes, and, in a more general way, in their modus operandi. Therefore, the world today faces a paradigm shift in scientific and innovation practices.

In the scientific context, the concept of open science is becoming popular. This approach to the scientific process consists of disseminating knowledge and results from the early stages of the process. It also aims at reducing barriers to access to results while open innovation focuses on opening the innovation process to experts in other fields, unlike traditional practice, which focused only on the company's internal human capital [Chesbrough, 2003].

Given the fact that Small and Medium Enterprises (SMEs) constitute the most significant number of companies within an economy [Friesike et al., 2015], it is essential to find ways to approximate open business models and the open innovation culture for this type of company. Defining a path toward innovation is particularly necessary for environments such as emerging economies, where the companies do not have enough resources to face such a change as, for instance, the partnerships created between universities and enterprises through collaborative tools to achieve innovative goals. These innovations contribute to information and knowledge sharing which influence competitiveness.

According to [Chesbrough, 2003], open innovation fosters the internal and external information flux internally and externally through different tools and allows for the incorporation of new perspectives in all stages of the value chain. The implementation of partnerships focused upon open innovation is fundamental to enterprise adaptation toward new business models and the implementation of best practices.

Germany has some initiatives concerning open science and open innovation because they encourage innovation and knowledge development. German researchers developed a framework of open science and innovation to lead the way toward strategic openness. Open innovation research is more popular than open science, so most studies do not connect the topics [Blümel et al., 2018].

Another example is Sweden, which developed an international partnership with Brazil. This partnership occurs through the Swedish-Brazilian Research and Innovation Centre (CISB) which encourages international collaboration between these two countries. The organization focuses on the partnership between government, academia, and industry to promote open innovation and open science. ${ }^{1}$

These partnerships are particularly important in emerging economies because they provide a solid foundation for the further development of these economies. The term "emerging economies" refers to the rapidly growing, but also volatile, economies of some Asian, African, and Latin American countries. They are also characterized by intermediate incomes and institutional transformations that lead to an economic opening [Vercueil, 2012].

Therefore, the purpose of this paper to delve into the intersection between open science and open innovation and demonstrate how SMEs can benefit from this connection and apply it in further product developments. Based on a Systematic Literature Review performed over four different scientific databases with international coverage, this article aims to answer the following research questions.

RQ1: What are the central topics in the literature about open science and open innovation?

RQ2: What are the differences and complementary elements between open science and open innovation?

\section{Open Science to Open Innovation}

Open Science is commonly defined as an umbrella term that embraces all the transformations occurring in scientific knowledge creation and dissemination, including open access, open data, open reproducible research, open science evaluation, open science policies, and open science tools. In the literature, OS is understood as knowledge, transparent knowledge, accessible knowledge, shared knowledge, and collaboratively developed knowledge [Vicente-Saez, Martinez-Fuentes, 2018]. The OS movement aims to apply the openness principles to all stages of the scientific process, from the hypothesis to data reuse. The opening process "drives collaboration and innovation and maximizes the potential to solve global challenges" [Ayris et al., 2018] and leads to a "new modus operandi for science" [European Commission, 2016]. It has been also pointed out that OS practices should always be adopted by scientists [Watson, 2015].

With the development of new working models, scientific practices should attract new industrial stakeholders leading to a potent combination of academic and industrial science. However, OS does not directly translate into innovations [Chesbrough, 2015]. One aspect is the clear difference in goals: scientific practice aims to generate foundation knowledge and prototype technologies, whereas enterprises are focused on product development. Innovation can be a secondary effect of science; however, there has to be a clear understanding of the OS movement and its implications among the scientific community, industry, and enterprises [Vicente-Saez, Martinez-Fuentes, 2018]. This understanding begins by elaborating upon the meaning of "open" in each of the movements. For OS, "open" refers to free access, without cost barriers or with as few barriers as possible. However, "open" in the context of OI means beyond barriers, that is, to be able to attract external

For more details see: http://www.cisb.org.br/, access date 07.11.2020. 
talent that complements the internal enterprise development through projects and strategic partnerships.

Considering the different stakeholders of the OS movement, there are four clear perspectives [Friesike et al., 2015]. The philanthropic perspective advocates for the democratization of science and focuses on open access to scientific content. The reflationary perspective emphasizes the importance of knowledge sharing at the beginning of the research process as a way to promote ideas within the scientific community. The constructivist perspective highlights that new knowledge also brings new opportunities for user models and business, for instance, the crowdsourcing model. Finally, the exploitative perspective points out how scientific knowledge sharing will lead to a smaller gap between university research and application-oriented knowledge. Following the latter, there is an ever-increasing interest within the scientific community to apply science to business problems [Chesbrough, 2015]. Consequently, universities around the world are now actively participating in enterprise incubator centers and public makerspaces and they have established Technology Transfer Offices (TTO) to manage and maximize the use of its intellectual property. All this is in line with the "entrepreneurial university" phenomenon [Etzkowitz et al., 2000] in order to connect university knowledge and practical knowledge, which is created by business processes.

Nonetheless, universities might need to adopt an enabling role in the process of opening innovation and also act as a main stakeholder. According to [GarcíaPeñalvo et al., 2010, p. 530], there are necessary actions for universities to take in order to enable the process: (1) promote an attitude of entrepreneurship, (2) adapt and evolve the educational model continuously in the country or region, using all possible opportunities, (3) combine entrepreneurship and education with a lifelong learning system, (4) support critical and freethinking, (5) maintain a structure within organizations to promote innovation, and (6) favor open innovation. It is essential to add the use and promotion of open licenses to these requirements. As indicated in the project FOSTER Open Science, open licenses, such as Creative Commons (CC), "amplify the affordances of digital technology and provide an enhanced means for social production in the networked economy" [European Comission, 2016]. The benefits of the acquisition of this type of license in business might have a direct impact upon cost reduction, the reduction of legal uncertainty, and the promotion of sustainability among SMEs. ${ }^{2}$

The implementation of open licenses also leads to a redefinition of intellectual property (IP), as indicated in the project FOSTER Open Science. IP should no longer be a defensive tool to protect knowledge but instead facilitates knowledge transfers between academia and industry and fosters transparency across the research and development (R\&D) system.

Both the OS movement and the OI movement imply a new mindset in how research and R\&D activities are developed. The OI movement established a contrast with the traditional vertical integration model where $\mathrm{R} \& \mathrm{D}$ activities, product development, and product distribution occurred exclusively inside and by the firm [West, Gallaguer, 2006]. On the other hand, the OS movement leads to the non-restricted distribution of research results and processes, coining terms such as open access, open data, open-source software, open collaboration, or open knowledge.

Even though both movements are separated currents, following the perspectives listed by Friesike et al. (2015), it is possible to distinguish some points of convergence between them. The philanthropic perspective brings science and research closer to society. This does not translate into OI; however, it can serve as a basis for developing OI projects if the right open business models are applied to foster benefits from the openness. For instance, makerspaces in academic libraries can be considered such a business model. The reflationary perspective fosters discussions from the very early stage of the research process. In the case of OI, this might be understood as an idea management process or even a design thinking process. However, with this process, OS aims to generate knowledge, whereas OI focuses on innovation and product development. The constructivist perspective places OS and OI one step closer by thinking of bringing new knowledge into new user models and new business. Virtual rooms and crowdsourcing models apply to both OS and OI, to enable knowledge fusion and the generation of innovative solutions. Research centers here acquire the role of knowledge intermediaries. This role is reflected in the exploitative perspective that leads to the concretization of openness effects. The application-oriented knowledge can be understood as a point of convergence between OS and OI.

\section{Methods}

Usually, these approaches do not reach the main scientific publication current and remain hidden. The purpose here is to provide an overview of open innovation and open science worldwide. This article presents an exploratory and quanti-qualitative investigation based on a Systematic Literature Review (SLR) [Tranfield et al., 2003; Cook, 1997]. The searching protocol described in Table 1 makes the research process more transparent and allows for its reproduction [Tranfield et al., 2003].

The selected databases were Web of Science, Scopus, Scientific Electronic Library Online (SciELO) and Brazilian database of Information Science periodical articles (BRAPCI). The first two databases facilitate the

\footnotetext{
2 See description of Creative Commons licenses and tools for businesses: https://docs.google.com/document/d/1rDLqZ95fatIAz-17efwJL7oXz9Y48peExZF4y4EQNks/edit, access date 07.11.2020.
} 
retrieval of transdisciplinary studies from global highimpact journals, whereas the third and the fourth enable the analysis of Latin American approaches to the topic, where the predominant languages are Spanish and Portuguese, respectively. The BRAPCI was chosen as a database because it provides papers in the Portuguese language, especially in the Information Science field. We did not limit the SLR by timeframes because the topic of this paper is innovative. Our goal was to retrieve as much as possible. A more exploratory research approach allowed us to look at the phenomena in a broader way.

The keywords used were open science and open innovation without quotes. The papers collected demonstrate how international academia has studied Open Science and Open Innovation together, whereas emerging economies still face challenges to establishing a relationship between business and academia. In fact, no article available at BRAPCI or SciELO combines both keywords either in its title or in its abstract or keywords of the study. Furthermore, Figure 1 shows the number of collected and selected articles.

The SLR enabled the recovery of 211 published articles on innovation and open science. A filtering process based on a review of the titles and keywords was performed, resulting in the selection of 88 articles (see Figure 2). A complete reading of the 88 articles was carried out in order to understand the approaches of the different topics across the literature in the area of Information Science. Other areas of knowledge, such as business management, public, or production engineering are also publishing about open innovation and open science. This fact demonstrates that there is a multidisciplinary interest in the subject, and therefore, there is the production of knowledge from various perspectives.

The retrieval was based on Boolean searches, using the operator 'AND' for the intersection of the terms 'open science' and 'open innovation' in order to find papers approaching OS and OI as compatible terms or those applying OS practices to innovation processes. If no result was found with this intersection in one specific database, as it was the case for BRAPCI and SciELO, the terms were searched for separately. The approaches presented in the retrieved papers were contrasted to find possible overlapping. Conference abstracts retrieved in Web of Science and Scopus were excluded from the final evaluation due to full-text unavailability. Because of being international databases, the content available in Web of Science and Scopus usually overlap. Consequently, eight of the ten articles selected from Web of Science were already in Scopus. Therefore, to avoid duplication, just two articles from Scopus were analyzed.

After that, the concepts of open science and open innovation were connected in a theoretical matrix. Table 1 presents the matrix with the central topics found in the articles and the number of articles following that perspective. This matrix shows how OS and OI can be connected, but also their divergences. The points of convergence of OS and OI, as well as the relevant aspects of each movement resulting from the SLR, are discussed in detail in Section 4.

The analysis of the papers allowed for the construction of Table 3 . The 74 papers were analyzed based on text marking tags. Table 3 shows the intersection between open science and open innovation identified in the papers. In addition to these papers, we incorporated other RSL about open science and open innovation which were published separately. There are eight RSL about open innovation and three about open science. Because of that, this paper focuses on the connection between these two concepts. Both lead to a different mindset in the way research and enterprise activities are conducted. However, even having overlapping topics, OS and OI develop separately.

\section{Results and Discussion}

Two different approaches to open innovation were identified in the papers. The first approach is related to the inter-organizational process, so the ideas are shared internally to create value. The second approach explains the connections between the organization and its external context, which is known as the ecosystem perspective. Both of them have something in common: the knowledge sharing with individuals and the creativity encouragement through learning.

According to Table 3, most of the papers explain the creation and dissemination of knowledge, stakeholders' partnerships, and knowledge use as a strategic tool. Therefore, there is a gap in the literature related to the application of open access in public management, culture, information management, and in the development of individual skills. These gaps are opportunities for the development of new scientific investigation.

\section{Open Innovation}

Most of the companies in emerging economies are categorized as small or medium enterprises. These businesses offer job opportunities and economic growth for the country [Carvalho, Sugano, 2016]. The SLR demonstrated only 28 papers that study open science and open innovation in the context of SMEs. Therefore, there is scope for further research on the opening of innovation and research projects.

There is a relationship between open innovation and the development of SMEs since knowledge allows one to find new markets and influence finances positively. Open innovation reduces innovation costs and helps knowledge management create new ideas [Henttonen, Lehtimaki, 2017; Akinwale, 2018; Bravo-Ibarra et al., 2014]. In fact, SMEs could develop more innovative products and ideas by avoiding working in an isolated way [Friesike et al., 2015]. Group business disseminates information to improve their research activities. 


\section{Figure 1. Protocol of SLR}

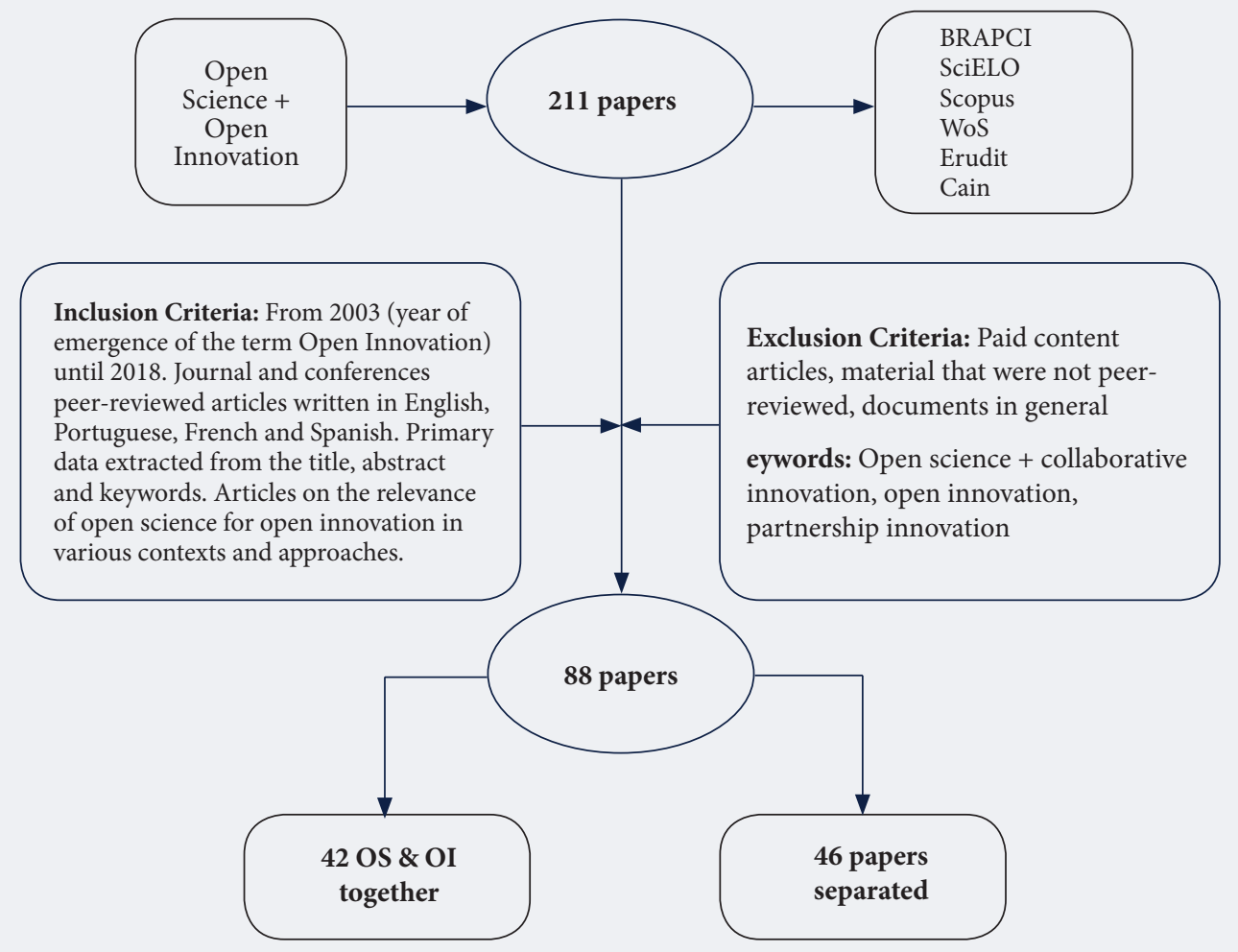

Source: elaborated by the authors.

Every organization needs to adopt a specific strategy to use open innovation such as Citizen Science [Gura, 2013], Open Access, and Open Data [Bernius, 2010; Sa, Grieco, 2016; Piedra, Suárez, 2018; Arza et al., 2017; Cardoso et al., 2009]. The selection of the tool depends upon the business goals, resources, and the time of innovation.

Beyond formal partnerships, businesses can use opensource software solutions and web-based tools, such as cloud computing, to apply open innovation strategies and collaboration [Roman et al., 2018; Schlagwein et al., 2017; Viseur, 2015; Bianchi et al., 2015; GarcíaPeñalvo et al., 2010]. "Strategic partnerships can be important strategies to be adopted in the context of disruptive innovations, such as cloud computing" [Cândido, Sousa, 2017]. The connected technology produces data and information which are shared in information systems of the business. The government actions can also encourage the network between business and university such as the aerospace industry in Brazil. This business agglomeration is important for the economy of Brazil since companies share information and sell products to Embraer. Embraer is a Brazilian company which produces airplanes internationally [Armellini et al., 2014].

Partnerships between universities and business complement the skills needed to improve the performance of the businesses [Azmi, Alavi, 2013; Dewes et al., 2010; Becker, Eube, 2018; Lucia et al., 2012]. Doing so, they will encourage open innovation and collaboration between businesses and universities.

There is an explanation of knowledge dissemination between partners: "entrepreneurial ecosystems may be superior to entrepreneurship alone" [Cooke, 2017]. These partnerships may reduce the research costs, create knowledge, encourage innovation, and share knowledge from educational organizations [Gold, 2016]. There is evidence of the advantages of Neuro Open Science created in Montreal demonstrated by [Gold, 2016], which is considered crucial to the growth of Neurosciences.

The growth of the collaboration between businesses and universities guides new insights that influence innovation. Open innovation allows this relationship to become a competitive advantage for both partners. "Given the different motivational backgrounds between private and public institutions, a symbiotic relationship becomes evident, where research institutions enable research capabilities, and private companies contribute commercialization know-how" [Friesike et al., 2015].

Open science brings with it the possibility of shared co-construction and the generation of open innovation to contribute to the public sphere as well as pri- 


\section{Table 1. Classification of the Articles by Number and Topic}

\begin{tabular}{|l|c|c|c|}
\hline \multicolumn{1}{|c|}{ Central Topics } & OS Only & OI Only & Both \\
\hline $\begin{array}{l}\text { Collaborative ecosystems and } \\
\text { new tools for collaboration }\end{array}$ & - & - & 17 \\
\hline Knowledge dissemination & - & - & 15 \\
\hline Open Source software & - & - & 4 \\
\hline $\begin{array}{l}\text { Intellectual property and } \\
\text { licenses }\end{array}$ & - & - & 4 \\
\hline Human capacities in strategy & - & - & 3 \\
\hline $\begin{array}{l}\text { Change in institutional } \\
\text { culture }\end{array}$ & - & - & 3 \\
\hline $\begin{array}{l}\text { Development for micro- and } \\
\text { small enterprises }\end{array}$ & - & 5 & - \\
\hline $\begin{array}{l}\text { Emerging technologies in } \\
\text { technology driven enterprises }\end{array}$ & - & 4 & - \\
\hline $\begin{array}{l}\text { Open Innovation as key for } \\
\text { product development }\end{array}$ & - & 4 & - \\
\hline $\begin{array}{l}\text { Information management as } \\
\text { tool for innovation }\end{array}$ & - & 4 & - \\
\hline $\begin{array}{l}\text { Open Innovation focused on } \\
\text { strategy }\end{array}$ & - & 4 & - \\
\hline $\begin{array}{l}\text { Open Innovation in public } \\
\text { management }\end{array}$ & - & 3 & - \\
\hline Public policy development & 4 & - & - \\
\hline TOTAL & 10 & 64 & 74 \\
\hline Source: elaborated by the authors. & & & \\
\hline
\end{tabular}

vate contexts. Although the contributions have been provided in the last decades, there is still much to be done in the practices of open science and the challenges to overcome in order to keep expanding upon the subject of open science [Ramírez-Montoya, García-Peñalvo, 2018]. The decision to participate in OS is not only an internal decision of the firm but is also dependent upon interactions with academic partners [Simeth, Raffo, 2013].

Open innovation neither refers to knowledge and technology access nor to knowledge dissemination, but to forms of decentralized information which are shared [Dillaerts, 2017; Guichard, Tran, 2006]. The authors use the decentralized expression for such information to explain the lack of hierarchy, so information and knowledge can be disseminated at every level. This sharing may occur in a virtual environment to create new data, information, and knowledge [Roman et al., 2018]. A similar idea is emphasized in [Schlagwein et al., 2017]: "Openness is an important and powerful concept, especially in combination with IT. Key "open" aspects - such as resources access and process participation - can be increased or enacted in entirely new ways through IT."

Open innovation is a useful tool since it can be considered the systematic integration of collaborative, sourcing, and revealing practices into a firm's business strategy [Armellini et al., 2014; Harison, Koski, 2010]. Therefore, businesses can use many methods and tools to enable partnerships.
Chesbrough [Chesbrough, 2006] highlights the characteristics of open innovation that guide the partnerships such as context perception, knowledge creation, the importance of knowledge sources to organizational culture, the role of business models in $\mathrm{R} \& \mathrm{D}$, acquisition availability, partnerships of co-development, identification of project failure, the relevance of knowledge flow, intellectual property management, the relevance of intermediaries in the innovation chain, the intensity of ICT use, and the evaluation of R\&D performance. These characteristics are also present when addressing collaboration for product development [Katsikis et al., 2016; Bueno, Balestrin, 2012; Griffin et al., 2014; Rubera et al., 2016] and knowledge management [ $W u, H u$, 2018; Grimsdottir, Edvardsson, 2018; Celadon, 2014].

The elements exposed by [Chesbrough, 2006] are crucial to open organization since they contribute to developing quality innovation. Furthermore, they help to evaluate the projects and to face the challenges of open innovation.

Apart from these challenges, another aspect to be taken into consideration is the institutional and cultural factors when implementing open innovation practices. For instance, the open business model studies are almost exclusively American and European, leaving African countries and other emerging economies out of the analysis [Khumalo, van der Lingen, 2017].

The type of SME plays a determinant role. Whereas technology-driven enterprises [Rodrigues et al., 2010; Henttonen, Lehtimaki, 2017], biotech companies, and construction companies [Vlaisavljevic et al., 2020; Jamett et al., 2017] might have a stronger connection with innovation, other industries such as tourism [Iglesias-Sánchez et al., 2019] still must define a strategy and systemized open innovation to explore its potential.

\section{Open Science}

For universities and public research institutions, OS means being able to share research results in an unrestricted and free of charge manner. This action aims to achieve a fair way of conducting research, as well as to create a supportive environment for the rapid and more accurate development of science. A well-configured OS strategy opens the door for open innovation and contributes to both the public and the private sphere [Ramírez-Montoya, García-Peñalvo, 2018]. Collaborative practices enlarge the number of stakeholders in the research ecosystem, who "will benefit from Open Science, although it will change work habits and business models" [Crouzier, 2015].

The concept of the ecosystem is recent in the academic context. For several authors, a cluster is also an extension of the value chain. This concept was created due to the complexity of the current context of clusters that demand new relationships with the external environment. Ecosystems are structured in an open innovation model and combine their ability to generate technolo- 


\section{Table 2. A Comparison between Open Science and Open Innovation}

\begin{tabular}{|c|c|c|c|}
\hline $\begin{array}{l}\text { Distinctive Attributes } \\
\text { of OI }\end{array}$ & Perspectives in OS & Convergence of Perspectives & Sources \\
\hline $\begin{array}{l}\text { New perception of the } \\
\text { external knowledge } \\
\text { generation scenario }\end{array}$ & $\begin{array}{l}\text { Philanthropic perspective - } \\
\text { approaches of science and } \\
\text { research to society }\end{array}$ & $\begin{array}{l}\text { Externally produced knowledge is } \\
\text { considered necessary. Enterprises use } \\
\text { competitive technological intelligence } \\
\text { and science integrates citizen science. } \\
\text { Appropriate open business models are } \\
\text { required. }\end{array}$ & $\begin{array}{l}\text { [Ramírez-Montoya, García-Peñalvo, } \\
\text { 2018; Smith, Seward, 2017; Cooke, } \\
\text { 2017; Gold, 2016; Viseur, 2015; Freitas, } \\
\text { Dacorso, 2014; Sánchez-González, } \\
\text { Herrera, 2014; Azmi, Alavi, 2013; } \\
\text { Simeth, Raffo, 2013; Stodden, 2010] }\end{array}$ \\
\hline $\begin{array}{l}\text { Importance of external } \\
\text { and internal knowledge } \\
\text { sources in organizational } \\
\text { culture and throughout } \\
\text { the process }\end{array}$ & $\begin{array}{l}\text { Reflationary perspective - } \\
\text { knowledge sharing in early } \\
\text { stages and the promotion } \\
\text { of new scientific ideas }\end{array}$ & $\begin{array}{l}\text { External and internal knowledge } \\
\text { sources have a distinctive role. } \\
\text { Enterprises and science open } \\
\text { their knowledge generation cycles } \\
\text { to networks and allow for the } \\
\text { contributions from the first stages of } \\
\text { innovation or research processes. }\end{array}$ & $\begin{array}{l}\text { [Roman et al., 2018; Schlagwein et } \\
\text { al., 2017; Dillaerts, 2017; Arza et al., } \\
\text { 2017; Fressoli, Arza, 2017; Friesike et } \\
\text { al., 2015; Simeth, Raffo, 2013; Touati, } \\
\text { Denis, 2013; Cardoso et al., 2009] }\end{array}$ \\
\hline $\begin{array}{l}\text { Central role of the } \\
\text { business model in R\&D } \\
\text { management }\end{array}$ & $\begin{array}{l}\text { Constructivist } \\
\text { perspective - collaborative } \\
\text { forms of knowledge } \\
\text { creation and new user } \\
\text { models }\end{array}$ & $\begin{array}{l}\text { Technology and scientific results } \\
\text { enlarge the number of available assets } \\
\text { (open technology, open software, open } \\
\text { data, etc.). There is a focus on the } \\
\text { added value. }\end{array}$ & $\begin{array}{l}\text { [Khumalo, van der Lingen, 2017; } \\
\text { Ngongoni et al., 2017; Alvarez-Aros, } \\
\text { Bernal-Torres, 2017; Katsikis et al., } \\
\text { 2016; Carvalho, Sugano, 2016; Bravo- } \\
\text { Ibarra et al., 2014; Bueno, Balestrin, } \\
\text { 2012; Saebi, Foss, 2015; Feller et al., } \\
\text { 2011; Berglund, Sandström, 2013; Yun } \\
\text { et al., 2016] }\end{array}$ \\
\hline Acquisition readiness & $\begin{array}{l}\text { Constructivist } \\
\text { perspective - development } \\
\text { and use of virtual exchange } \\
\text { platforms }\end{array}$ & $\begin{array}{l}\text { Enterprises focus their acquisition } \\
\text { efforts on innovative and technology- } \\
\text { based companies to improve and } \\
\text { accelerate the technical infrastructure. } \\
\text { Scientific practices use appropriate } \\
\text { infrastructure for data-driven research } \\
\text { with distributed computing as a base. }\end{array}$ & $\begin{array}{l}\text { [Ramírez-Montoya, García-Peñalvo, } \\
\text { 2018; Rodrigues et al., 2010; García- } \\
\text { Peñalvo et al., 2010] }\end{array}$ \\
\hline $\begin{array}{l}\text { Use of co-development } \\
\text { partnerships }\end{array}$ & $\begin{array}{l}\text { Reflationary perspective - } \\
\text { feedback from colleagues } \\
\text { and joint collaborative } \\
\text { knowledge creation }\end{array}$ & $\begin{array}{l}\text { Innovation and research processes } \\
\text { benefit from the collaboration with } \\
\text { external partners, leading to enhanced } \\
\text { results. }\end{array}$ & $\begin{array}{l}\text { [Akinwale, 2018; Lopes et al., 2017; } \\
\text { Merino et al., 2015; Schuster, Brem, } \\
\text { 2015; Scuotto et al., 2020] }\end{array}$ \\
\hline $\begin{array}{l}\text { Mitigation of R\&D } \\
\text { project failures }\end{array}$ & $\begin{array}{l}\text { Reflationary perspective - } \\
\text { avoidance of local research } \\
\text { bias and fast error } \\
\text { identification }\end{array}$ & $\begin{array}{l}\text { New business and science evaluation } \\
\text { models characterized by open practices } \\
\text { allow for rapid error identification and } \\
\text { enable process improvement. }\end{array}$ & $\begin{array}{l}\text { Uamett et al., 2017; De Pablos- } \\
\text { Heredero et al., 2013; Dewes et al., } \\
\text { 2010; Gerhart et al., 2000; Strasak et } \\
\text { al., 2007; Lee et al., 2012] }\end{array}$ \\
\hline $\begin{array}{l}\text { Importance of the flow of } \\
\text { knowledge outputs }\end{array}$ & $\begin{array}{l}\text { Constructivist } \\
\text { perspective - availability } \\
\text { of open platforms } \\
\text { and interdisciplinary } \\
\text { integration }\end{array}$ & $\begin{array}{l}\text { Knowledge outputs openly available, } \\
\text { even when not directly connected } \\
\text { with the main aim of the innovation } \\
\text { or research process, can generate new } \\
\text { perspectives for the development of } \\
\text { infrastructure or enterprises (such as } \\
\text { start-ups). }\end{array}$ & $\begin{array}{l}\text { [Armellini et al., 2014; Celadon, } \\
\text { 2014; Remneland-Wikhamn, 2013; } \\
\text { Calderón-Martínez, 2009, 2010] }\end{array}$ \\
\hline $\begin{array}{l}\text { Intellectual property } \\
\text { management model }\end{array}$ & $\begin{array}{l}\text { Exploitative perspective - } \\
\text { generation of scientific } \\
\text { findings with real-life } \\
\text { applications }\end{array}$ & $\begin{array}{l}\text { IP management is based on free } \\
\text { licenses, for instance CC licenses in } \\
\text { science and enterprises. These licenses } \\
\text { amplify the affordability of digital } \\
\text { technology and provide an enhanced } \\
\text { means for social production in the } \\
\text { networked economy. }\end{array}$ & [Roman et al., 2018] \\
\hline $\begin{array}{l}\text { Importance of new } \\
\text { intermediaries in the } \\
\text { innovation chain }\end{array}$ & $\begin{array}{l}\text { Reflationary perspective - } \\
\text { introduction of groupthink } \\
\text { and idea sharing within the } \\
\text { community }\end{array}$ & $\begin{array}{l}\text { New external intermediaries take over } \\
\text { actions that were previously internal. } \\
\text { This is likely to happen at all stages of } \\
\text { the research or innovation process, } \\
\text { through openly sharing of activities } \\
\text { and accepting external participation } \\
\text { (e.g., Citizen Science). }\end{array}$ & [Callon, 2012; Schenk, Guittard, 2012] \\
\hline $\begin{array}{l}\text { Intensity in the use of } \\
\text { ICT }\end{array}$ & $\begin{array}{l}\text { Exploitative perspective -- } \\
\text { shared construction of ICT } \\
\text { artifacts }\end{array}$ & $\begin{array}{l}\text { The technical infrastructure enables } \\
\text { activity management in both the } \\
\text { innovation and the research process. } \\
\text { Therefore, ICT is considered essential. }\end{array}$ & $\begin{array}{l}\text { [Bianchi et al., 2015; Lakeman-Fraser } \\
\text { et al., 2016; Abbate et al., 2019] }\end{array}$ \\
\hline $\begin{array}{l}\text { Metrics for the } \\
\text { measurement of R\&D } \\
\text { performance }\end{array}$ & $\begin{array}{l}\text { Exploitative perspective - } \\
\text { measurement of research } \\
\text { application in academia } \\
\text { and beyond. }\end{array}$ & $\begin{array}{l}\text { Opening processes involve a renewal } \\
\text { of the metrics used to measure R\&D } \\
\text { performance and research article } \\
\text { impact. }\end{array}$ & $\begin{array}{l}\text { [Ajzen et al., 2016; Neely et al., 2005; } \\
\text { Gulbrandsen, Smeby, 2005; Breunig et } \\
\text { al., 2014; Chen et al., 2015] }\end{array}$ \\
\hline
\end{tabular}


gies with external partnerships. Innovation ecosystem theory is broader than the concept of systems of innovation, as it goes beyond the regional economy context and it is normally company- or technology-centered [Faissal-Bassis, Armelini, 2018].

There is a de facto convergence of academic and industrial science, especially for application-oriented purposes, which increases the importance of cooperation and understanding OS practices [Friesike et al., 2015]. Establishing cooperation models is necessary for strategic and tactical processes [Martínez-Noya, Narula, 2018]. The decision to participate in these cooperation models and the consequent development of an appropriate open business model depends upon the internal decisions of the firm and the interactions with academic partners [Simeth, Raffo, 2013]. In some cases, these interactions are not only limited to academic and industrial partners, but they progressively include other ways of collaboration, for example, with the general public [Fressoli, Arza, 2017]. In some cases, external and intermediary actors are essential to generating new technology, so they need to align their strategies and interests. Besides, the relevance of the knowledge and competence of the actors must not be forgotten [Federer et al., 2020].

Information technologies (IT) offer several tools in order to guarantee interactions among the research ecosystem, inside and outside academia, for instance to access resources and guarantee process participation [Schlagwein et al., 2017]. These tools can vary from online writing tools or academic social networks [ $\mathrm{Vi}$ seur, 2015] to virtual research environments (VREs). In fact, it is suggested that VREs "foster the transfer of research data from university to industry and its exploitation to generate new data sets, information and knowledge" [Roman et al., 2018].

Apart from that, IT solutions expand the scope and openness of academic research [Abbate et al., 2019; Arza et al., 2017]. Up to now, scientific public goods were limited to textual publications, however, nowadays, open data and open infrastructure are also part of these goods. Consequently, the use of new forms of evaluation of scientific production that include these research assets is required. Examples are usage metrics (measuring downloads and savings), alternative metrics (measuring research impact in Wikipedia, blogs, news, bookmark tools, and social media), or data citation.

If a well-configured OS strategy is combined with a well-configured OI strategy, enterprises will be more open to joining the research ecosystems that benefit their activities.

\section{Intersection between Open Science and Open Innovation}

There are distinguishing features between the attributes of OI in contrast with closed innovation [Ches- brough, 2006]. In order to see the intersection between OS and OI, we contrasted these attributes with the perspectives in OS described by [Friesike et al., 2015] and introduced above.

The following table (Table 2) presents a comparison between the attributes of OI and the perspectives in OS. The aim is to identify a convergence of the perspectives and distinguish possible areas for joint action.

In the process of open innovation, the involved individuals develop the perception of the scenario and the relevance of knowledge generation. At the same time, open innovation aims to provide information and knowledge through quality sources [Ramírez-Montoya, García-Peñalvo, 2018; Smith, Seward, 2017; Cooke, 2017; Gold, 2016; Viseur, 2015; Sánchez-González, Herrera, 2014; Freitas, Dacorso, 2014; Azmi, Alavi, 2013; Simeth, Raffo, 2013; Stodden, 2010]. Thus, it manages the results of production through collaborative networks and, eventually, through social networks for users [ $\mathrm{Vr}$ govic et al., 2012; Liu et al., 2017]. Therefore, learning about academic information enables the understanding of the context and creates strategies to overcome the challenges.

The relative importance of knowledge [Secundo et al., 2019; Akinwale, 2018] sources should be emphasized in a company's culture, as managers and employees start to value the sources of quality information. The opening of the innovation processes is marked by the massive production of data and information [Schwab, 2016], so they must know how to deal with false information. In the academic field, open science seeks to provide information and knowledge through quality sources. That is why it is considered necessary to publish partial results and research data from the early stages of the process. On the other hand, a way to review these early-stage results is required to guarantee content quality. In this sense, some platforms are developed for the evaluation of results by the scientific community, for example RIO (for grant proposal), Hypothesis.is (for commenting openly), or Protocols.io (for protocols and workflows).

The management of the development of new products and services is necessary as there is a progressive increase in information [Nambisan et al., 2017]. Such an increase also occurs in universities. Therefore, editors must manage scientific articles, authors, and reviewers for the organization of the process. In this sense, new evaluation possibilities and methodologies are also valued, for example, collective evaluation on open platforms, especially when dealing with large data sets and not with a single textual publication, as explained in the project FOSTER Open Science.

Time becomes a great challenge because the academic knowledge focused on business competitiveness must obey the deadlines, be developed with quality, and done so more rapidly in order to accompany the business transformations. To this end, the partnership between enterprises and universities is central for both 
organizations to benefit from collaborative learning [Chesbrough, 2015].

Open innovation partnerships require readiness for technological and human capital acquisitions [Belenzon, Schankerman, 2015]. Open science also needs to invite researchers considered relevant to the field. It must have an online domain and be easy to communicate with the user. Besides, both open science and open innovation are looking for innovative methods [Chesbrough, 2006] suitable for new intelligent production methods and spaces. Examples of these spaces are virtual research environments or makerspaces.

The use of co-development partnerships occurs through research institutions, universities, industrial clusters, companies, trade and industrial associations, and government agencies [Roman et al., 2018]. In the context of open science, many partnerships are made through virtual collaboration [Friesike et al., 2015; Simeth, Raffo, 2013]. In addition, research groups attract international knowledge due to open access to publications. Therefore, the interlocking relationships between innovation and open science can bring together various organizations to share the results of the research and development of practical projects as well as forms of joint project funding with the government. The mitigation of project failures means analyzing the problems that arose during the collaborative innovation project. This phase makes it possible to improve processes and save time in the future. In open science, results are available from the beginning of the research cycle, which allows peers to identify their failures and evaluate projects that have not worked to improve processes. As many companies are still in transition to open innovation, this process is crucial in order to adapt the organizational routine to achieve the proposed goals.

Open innovation has as its central focus the flow of knowledge outputs. This flow is the product of learning between the companies and organizations involved in the partnership. Open access values the availability of information to generate knowledge [Bernius, 2010; Jamett et al., 2017; Pitassi, 2012]. Thus, journals value the publication of the numbers and share them with the companies and industrial agglomerations. Thus, it can offer a useful service, disseminating quality knowledge to both researchers and professionals.

New ideas and innovation are transformed into intellectual property by companies. Thus, they apply models of management of this property [Brem et al., 2017]. In this sense, it is convenient to analyze the application of open licenses, both for scientific and business products, to reduce costs and ensure sustainability. Thus, innovation and open science are concerned both with intellectual property and the right to ideas in university-business partnerships [Roman et al., 2018].

The importance of intermediaries in the innovation chain influences the information flows of open innovation since the actors need to share knowledge intel- ligently. Effective communication between the evaluator and the researcher is a key factor for open science, which is why the open-peer review is introduced. Communication plays a crucial role in the insertion of external actors (e.g., citizen scientists) to have control over data collection and the obtaining of results [Lewis, 2020; Callon, 2012; Schenk, Guittard, 2012]. It is necessary to know the limitations of the research or project, suggest clear improvements, remove doubts from users, and manage exchanges between academics and managers.

The intensity in the use of ICT and measures of performance evaluation of $R \& D$ are also part of the concepts of open innovation. Open science uses modern systems and online domains to organize and process information [Doyle et al., 2019; Álvarez-Aros, BernalTorres, 2017; Khumalo, van der Lingen, 2017; Katsikis et al., 2016; Carvalho, Sugano, 2016; Bravo-Ibarra et al., 2014; Bueno, Balestrin, 2012; Ngongoni et al., 2017]. The focus is on those who respect a sustainable information architecture and ensure that data is findable, accessible, interoperable, and reusable. Open science and open innovation contribute to the dissemination of partnerships between academia and business, stimulating them in emerging economies [Chaston, Scott, 2012; Kafouros, Forsans, 2012]. Such partnerships provide the opportunity to take advantage of market opportunities in Industry 4.0 [Carvalho, Sugano, 2016]. In the context of Industry 4.0, ICTs are considered intelligent because they are connected, produce, and transfer data and information. The framework below illustrates the connection between open science and innovation.

\section{Open Science and Open Innovation in Emerging Economies}

Given the inclusion in the SLR of databases such as SciELO, whose scope is mainly Latin America and some African countries (such as South Africa), the SLR also delivered some facts about OS and OI approaches in emerging economies.

As stated by [Friesike et al., 2015], SMEs represent the most significant number of companies within an economy. However, the issue of how SMEs in emerging economies can benefit from open innovation practices has not been explored in depth in the literature [Khumalo, van der Lingen, 2017] and there is a need for designing requirements for an open innovation approach in these economies [Krause, Schutte, 2015].

In some cases, the need for a basis for technology transfer and knowledge management is pointed out in order to create a solid industrial network [Lehtimaki et al., 2009; Valencia-Vazquez et al., 2014; Jamett et al., 2017; Pitassi, 2012]. Such a solid network allows for crossing firm boundaries and implies that both internal and external knowledge can find their way to commercialization for existing or new markets [Amponsah, Adams, 2017; Akinwale, 2018] and find potential 
new clients [Merino et al., 2015]. Collaboration with academic partners might also lead to the better development of public policies for idea generation, activity control, and patent registry [Bianchi et al., 2015; García-Peñalvo et al., 2010]. It is worth mentioning that the validation of collaborative practices also involves an in-depth study of IP and IP policies in open innovation strategies [Hagedoorn, Zobel, 2015; Lichtenthaler, 2010; Bianchi et al., 2015; Bravo-Ibarra et al., 2014]. The development of these policies turns governments also into important actors in the OS and OI process [Sa, Grieco, 2016; Yoon, 2017; Freitas, Dacorso, 2014].

How OS and OI are addressed in a particular territory has a strong dependence upon culture. More collectivistic societies, such as China, are more likely to favor cooperative initiatives, whereas other societies might follow a more individualistic approach [Cooke, 2017].

Cultural aspects also affect the modus operandi of a community. In some cases, the adoption of open strategies generates a "culture of the fear". Among the scientific community, it is fear of information misuse or misinterpretation [Fressoli, Arza, 2017]. Among enterprises, it is fear of sharing strategic information, even though this sharing might attenuate risks and increase efficiency [Riley et al., 2016; Cândido, Sousa, 2017; De Pablos-Heredero et al., 2013]. In fact, this dissemination can occur ethically, for instance, following best practices for knowledge sharing such as the adoption of open licenses in both academia and industry. In this sense, enterprises benefit from ecosystem engagement and value creation when building a culture of collaboration and information-sharing [Ngongoni et al., 2017]. Another aspect highlighted in the literature about emerging economies is the building of new competencies. One of the primary motivations for collaboration between universities and enterprises is the reduction of time for innovation by means of learning [Morandi, 2013; Perkmann, Walsh, 2007; Lopes et al., 2017]. As a result, individuals can acquire and develop new skills during their practices in the process of open innovation. Furthermore, they can learn from the information openly available in a long-life learning process. Therefore, enterprises should focus on the role of human talent as a strategy to boost innovation capacities [Bartelsman et al., 2015; Álvarez-Aros, Bernal-Torres, 2017]. On the other hand, universities might adopt an intermediary role offering the knowledge and expertise on new technologies and on information literacy [Ottonicar et al., 2018]. Connected technology, such as cloud computing, produces data and information which are shared in the information systems of the businesses, requiring sustainable infrastructure for data archiving and preservation.

Finally, innovative activities in enterprises should be monitored as a way to evaluate performance. On the other hand, inside academia, the way research performance is evaluated should also consider further pa- rameters due to the fact that research outputs embrace not only articles but also data or infrastructure [Arza et al., 2017].

Open science and open innovation practices can be adopted simultaneously by academics, researchers, managers, and employers in the partnerships. The aim is to share information and knowledge about processes, products, and services which are demanded by consumers in a technology-driven context, which requires immediacy in development. Public policies serve as the first step for university-enterprise engagement in emerging economies. Apart from that, it is necessary to establish workflows that help in the management data, information, and knowledge transfer between all stakeholders. According to [Serrano-Bedia et al., 2018] a variety of sources of knowledge influence innovation. Therefore, stakeholders are relevant sources of knowledge.

This paper proposes the following framework (Figure 2) so that innovation can be achieved by the connection between OS and OI.

Open science is connected to policy makers because scientific knowledge contributes to the development of economic policy [Sa, Grieco, 2016; Arza et al., 2017; Freitas, Dacorso, 2014]. Open innovation encourages the relationship between business, research institutes, and the government, and it creates an organizational structure to connect business, universities, and policy makers.

Both open innovation and open science generate and use knowledge. Lifelong learning creates knowledge [Fletcher et al., 2010; Jamett et al., 2017; Pitassi, 2012]. That learning is based on applied and basic research [Akinwale, 2018; Álvarez-Aros, Bernal-Torres, 2017]. Therefore, knowledge and infrastructure influence business competitiveness [Serrano-Bedia et al., 2018]. Furthermore, competitiveness needs open science, open innovation, and public policy to encourage knowledge sharing between business and universities [Bianchi et al., 2015; García-Peñalvo et al., 2010].

Economic policy must encourage open innovation to help businesses grow through partnerships [Schuster, Brem, 2015; Freitas, Dacorso, 2014]. Researchers must study the fact that "the public action towards innovation has changed to foster more collaborative and open innovation" [Jugend et al., 2020]. Therefore, policy makers, open innovation, and open science influence the competitive advantage of countries.

\section{Conclusions}

In this paper we performed an SLR to delve into the intersection between open science and open innovation and demonstrate how emerging economies can benefit from this connection and apply it in further product developments. Only 28 papers connected both themes, so we encourage both fields of business management 
and information science to develop research about the subject.

The SLR demonstrated that most papers connect open science and open innovation in "collaborative ecosystems and new tools for "collaboration" and "knowledge dissemination". Only a few papers mentioned the development of open-source software, intellectual property and licenses, and human skills for strategy and organizational culture change. Furthermore, some papers had a multidisciplinary perspective because they identified the relevance of open science to cultural influence and public organization management.

Open science and open innovation can be connected to improve knowledge sharing, stakeholders' partnerships and this can be done in the context of SMEs. Furthermore, the papers explained open science and open innovation as a strategy to achieve competitiveness, financial performance, and the development of human capital focused on creativity, entrepreneurship, disruptive technology, product innovation, and public management.

Open innovation creates a new structure in the ecosystem because it connects businesses, universities, and the government. Open science shares theoretical and practical knowledge in order to feed open innovation. Furthermore, open science provides information for the development of economic policy.

There is a gap in the literature which connects open science and open innovation in developing countries. That type of research is relevant since emerging economies have difficulties related to financial investment and qualified human capital. Furthermore, the major-

\section{Figure 2. Innovation Flow Combining Open Science and Open Innovation}

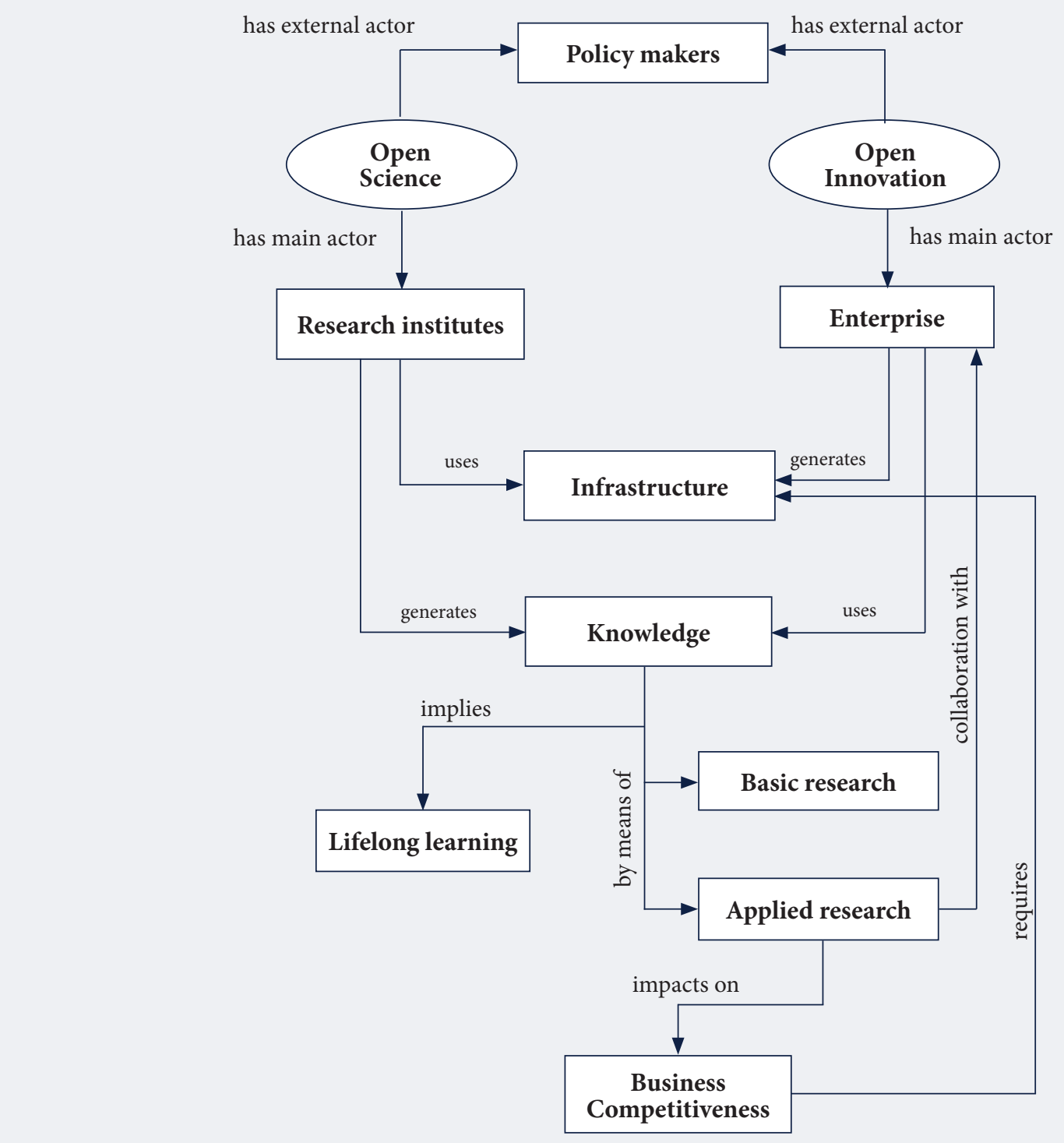


ity of companies are SMEs, so they need to be the focus of economic policy.

The topic of this paper is recent and innovative. There were not a lot of papers that discuss open science and open innovation together. If we restricted our search to only high impact journals there would not be enough evidence for a rigorous analysis. A more exploratory research approach allowed us to look at a broader base. Furthermore, we used other databases to retrieve papers in French, Portuguese, and Spanish. The SLR in other languages helped us to identify how emerging economies like Latin America have studied the topic to improve their economy. SciELO and BRAPCI are databases that share papers from Latin America, which includes emerging economies.

In conclusion, the connection between open science and open innovation is fundamental to encouraging partnerships between businesses and universities. This kind of partnership contributes to the economy of developing countries. Industry 4.0 is a challenge for developing countries since it demands high investment in smart technology and people training. Open access and open innovation may be used by these countries as part of their economic strategy to overcome these challenges.

This paper is not free from limitations. The first limitation is based on language due to the authors' knowledge, only papers in English, Portuguese, Spanish, and
French were considered. Another limitation is that only indexed papers are considered, excluding conference papers and grey literature. The results can be adapted and applied in other developing countries to help foster economic growth.

Future research may develop practical studies about the relationship between businesses and universities in the context of emerging economies. These partnerships can improve the processes, encourage creativity, and contribute to the competitive advantage of both public and private organizations. Furthermore, we highly recommend papers that discuss workflow analysis to share data between businesses and universities, information literacy for information dissemination, and legal licenses for open innovation.

Open science can be used as a tool for individuals to learn new approaches and innovate in a business context. Innovation is fundamental to growth and organizational competitiveness, especially in the context of I4.0. Businesses can be open and relate to other organizations to share knowledge.

We would like to thank the Coordenação de Aperfeiçoamento de Nivel Superior (CAPES, Coordination for the Improvement of Higher Education Personnel), Conselho Nacional de Desenvolvimento Científico e Tecnológico (CNPq, National Council for Scientific and Technological Development) and The Fonds de Recherche du Québec - Nature et Technologie (FRQNT) for the development of this research.

\section{References}

Abbate T., Codini A.P., Aquilani B. (2019) Knowledge Co-creation in Open Innovation Digital Platforms: Processes, Tools and Services. Journal of Business and Industrial Marketing, vol. 34, no 7, pp. 1434-1447. Available at: https://doi.org/10.1108/ JBIM-09-2018-0276, accessed 07.11.2020.

Ajzen M., Rondeaux G., Pichault F., Taskin, L. (2016) Performance et innovation en PME: Une relation à questioner. Revue Internationale P.M.E., vol. 29, no 2, pp. 65-94. Available at: https://doi.org/10.7202/1037923ar, accessed 07.11.2020.

Akinwale Y.O. (2018) Empirical analysis of inbound open innovation and small and medium-sized enterprises' performance: Evidence from oil and gas industry. South African Journal of Economic and Management Sciences, vol. 21, no 1, art. a1608. Available at: https://doi.org/10.4102/sajems.v21i1.1608, accessed 07.11.2020.

Alvarez-Aros E.L., Bernal-Torres C.A. (2017) Modelo de Innovacion Abierta: Enfasis en el Potencial Humano. Informacion Tecnologica, vol. 28, no 1, pp. 65-76. Available at: https://doi.org/10.4067/S0718-07642017000100007, accessed 07.11.2020.

Amponsah C.T., Adams S. (2017) Open innovation: Systematisation of knowledge exploration and exploitation for commercialization. International Journal of Innovation Management, vol. 21, no 3. Art.1750027. DOI: 10.1142/S136391961750027X.

Armellini F., Kaminski P.C., Beaudry C. (2014) The Open Innovation Journey in Emerging Economies: An Analysis of the Brazilian Aerospace Industry. Journal of Aerospasce and Technology Management, vol. 6, no 4, pp. 462-474. DOI: 10.5028/ jatm.v6i4.390

Arza V., Fressoli M., Sebastian S. (2017) Towards open science in Argentina: From experiences to public policies. First Monday, vol. 22, no 7. Available at: https://doi.org/10.5210/fm.v22i7.7876, accessed 07.11.2020.

Ayris P., Bernal I., Cavalli V., Dorch B., Frey J., Hallik M., Hormia-Poutanen K., Labastida I., MacColl J., Ponsati-Obiols A., Sacchi S., Scholze F., Schmidt B., Smit A., Sofronijevic A., Stojanovski J., Svoboda M., Tsakonas G., van Otegem M., Verheusen A., Vilks A., Widmark W., Horstmann W. (2018) Liber Open Science Roadmap, Hague: Association of European Research Libraries. Available at: https://doi.org/10.5281/zenodo.1303002, accessed 07.11.2020.

Azmi I.M., Alavi R. (2013) Patents and the practice of open science among government research institutes in Malaysia: The case of Malaysian Rubber Board. World Patent Information, vol. 35, no 3, pp. 235-242. Available at: https://doi.org/10.1016/j. wpi.2013.03.005, accessed 07.11.2020.

Bartelsman E., Dobbelaere S., Peters B. (2015) Allocation of human capital and innovation at the frontier: Firm-level evidence on Germany and the Netherlands. Industrial and Corporate Change, vol. 24, no 5, pp. 875-949. Available at: https://doi. org/10.1093/icc/dtu038, accessed 07.11.2020.

Becker B.A., Eube C. (2018) Open innovation concept: integrating universities and business in digital age. Journal of Open Innovation: Technology, Market, and Complexity, vol. 4, art. 12. Available at: https://doi.org/10.1186/s40852-018-0091-6, accessed 07.11.2020. 
Belenzon S., Schankerman M., (2015) Motivation and sorting of human capital in open innovation. Strategic Management Journal, vol. 36, no 6, pp. 795-820. Available at: https://doi.org/10.1002/smj.2284, accessed 07.11.2020.

Berglund H., Sandström C. (2013) Business model innovation from an open systems perspective: Structural challenges and managerial solutions. International Journal of Product Development, vol. 18, no 3-4, pp. 274-285. DOI: 10.1504/ IJPD.2013.055011.

Bernius S. (2010) The impact of open access on the management of scientific knowledge. Online Information Review, vol. 34, no 4, pp. 583-603. Available at: https://doi.org/10.1108/14684521011072990, accessed 07.11.2020.

Bianchi I., Bigolin F., de Linhares Jacobsen A., 2015. As Tecnologias e Sistemas de Informacao como Ferramentas de apoio no Processo de Inovacao Aberta. Prisma.com, vol. 29, pp. 157-172. Available at: http://ojs.letras.up.pt/index.php/prismacom/ article/view/1836, accessed 07.11.2020.

Blumel C., Fecher B., Leimuller G. (2018) Was gewinnen wir durch Open Science und Open Innovation?, Essen: Edition Stifterverband.

Bravo-Ibarra E.R., Leon-Arenas A.P., Serrano-Cardenas L.F. (2014) Explorando las principales ventajas y factores de exito de la innovacion abierta en las organizaciones. Entramado, vol. 10, no 2, pp. 44-59. DOI: 10.18041/entramado.2014v10n2.20220.

Brem A., Nylund P.A., Hitchen E.L. (2017) Open innovation and intellectual property rights: How do SMEs benefit from patents, industrial designs, trademarks and copyrights? Management Decision, vol. 55, no 6, pp. 1285-1306. Available at: https://doi.org/10.1108/MD-04-2016-0223, accessed 07.11.2020.

Breunig K.J., Aas T.H., Hydle K.M. (2014) Incentives and performance measures for open innovation practices. Measuring Business Excellence, vol. 18, no 1, pp. 45-54. Available at: https://doi.org/10.1108/MBE-10-2013-0049, accessed 07.11.2020.

Bueno B., Balestrin A. (2012) Inovacao colaborativa: Uma abordagem aberta no desenvolvimento de novos produtos. Revista de Administracao de Empresas, vol. 52, pp. 517-530. Available at: https://doi.org/10.1590/S0034-75902012000500004, accessed 07.11.2020.

Callon M. (2012) Quel role pour les sciences sociales face a l'emprise grandissante du regime de l'innovation intensive ? Cahiers de Recherche Sociologique, vol. 53, pp. 121-165. Available at: https://doi.org/10.7202/1023194ar, accessed 07.11.2020.

Candido A.C., Sousa C. (2017) Open Innovation Practices in Strategic Partnerships of Cloud Computing Providers. Journal of Technology Management and Innovation, vol. 12, no 2, pp. 59-67. Available at: https://doi.org/10.4067/S071827242017000200007, accessed 07.11.2020.

Cardoso G., Caraca J., Espanha R., Triaes J., Mendonca S. (2009) As politica de Open Access: Res publica cientifica ou autogestao? Sociologia, Problemas e Praticas, vol. 60, pp. 53-67.

Carvalho E.G., Sugano J.Y. (2016) Entrepreneurial orientation and open innovation in Brazilian startups: A multicase study. Interacoes, vol. 17, no 3, pp. 448-462. Available at: http://dx.doi.org/10.20435/1984-042X-2016-v.17-n.3(08) , accessed 07.11.2020.

Celadon K.L. (2014) Knowledge Integration and Open Innovation in the Brazilian Cosmetics Industry. Journal of Technology Management and Innovation, vol. 9, no 4, pp. 34-50. Available at: https://doi.org/10.4067/S0718-27242014000300003, accessed 07.11.2020.

Chaston I., Scott G.J. (2012) Entrepreneurship and open innovation in an emerging economy. Management Decision, vol. 50, no 7, pp. 1161-1177. Available at: https://doi.org/10.1108/00251741211246941, accessed 07.11.2020.

Chen J., Zhao X., Wang Y. (2015) A new measurement of intellectual capital and its impact on innovation performance in an open innovation paradigm. International Journal of Technology Management, vol. 67, art. 1, pp. 1-25. DOI: 10.1504/ IJTM.2015.065885.

Chesbrough H.W. (2003) Open innovation: The new imperative for creating and profiting from technology, Boston, MA: Harvard Business School Press.

Chesbrough H.W. (2006) Open business models: How to thrive in the new innovation landscape, Boston, MA: Harvard Business School Press.

Chesbrough H.W. (2015) From Open Science to Open Innovation, Barcelona: ESADE.

Cook D.J. (1997) Systematic Reviews: Synthesis of Best Evidence for Clinical Decisions. Annals of Internal Medicine, vol. 126, pp. 376-380. Available at: https://doi.org/10.7326/0003-4819-126-5-199703010-00006, accessed 07.11.2020.

Cooke P. (2017) 'Digital tech' and the public sector: What new role after public funding? European Planning Studies, vol. 25, no 5, pp. 739-754. Available at: https://doi.org/10.1080/09654313.2017.1282067, accessed 07.11.2020.

Crouzier T. (2015) Science Ecosystem 2.0: How will change occur? Luxembourg: EU Publications Office. Available at: https:// ec.europa.eu/research/innovation-union/pdf/expert-groups/rise/science_ecosystem_2.0-how_will_change_occur_crouzier_072015.pdf, accessed 07.11.2020.

De Pablos-Heredero C., Soret-LosSantos I., Lopez-Eguilaz M.J. (2013) Un modelo de Medicion de Resultados en las Practicas de Innovacion Abierta. Journal of Technology Management and Innovation, vol. 8, no 1, pp. 73-74. Available at: https://doi. org/10.4067/S0718-27242013000300037, accessed 07.11.2020.

Dewes M.F., Goncalez O.L., Passaro A. (2010) Open innovation as an alternative for strategic development in the aerospace industry in Brazil. Journal of Aerospasce and Technology Management, vol. 2, no 3, pp. 349-360. Available at: https://doi. org/10.5028/jatm.2010.02038910, accessed 07.11.2020.

Dillaerts H. (2017) Ouverture et partage des resultats de la recherche dans l'economie de la connais-sance europeenne: Quelle(s) liberte(s) de circulation pour l'IST? Communication et Management, vol. 14, no 1, pp. 39-54. Available at: https:// doi.org/10.3917/comma.141.0039, accessed 07.11.2020.

Doyle C., Luczak-Roesch M., Mittal A. (2019) We Need the Open Artefact: Design Science as a Pathway to Open Science in Information Systems Research. Extending the Boundaries of Design Science Theory and Practice. Proceedings of the DESRIST 2019 Conference (eds. B. Tulu, S. Djamasbi, G. Leroy), Heidelberg, New York, Dordrecht, London: Springer, pp. 46-60. Available at: https://doi.org/10.1007/978-3-030-19504-5_4, accessed 07.11.2020. 
Etzkowitz H., Webster A., Gebhardt C., Terra B.R.C. (2000) The future of the university and the university of the future: Evolution of ivory tower to entrepreneurial paradigm. Research Policy, vol. 29, no 2, pp. 313-330. Available at: https://doi. org/10.1016/S0048-7333(99)00069-4, accessed 07.11.2020.

European Commission (2016) Open innovation, open science, open to the world: A vision for Europe, Luxembourg: Publications Office of the European Union. Available at: https://doi.org/ 10.2777/061652, accessed 07.11.2020.

Faissal Bassis N., Armellini F. (2018) Systems of innovation and innovation ecosystems: a literature review in search of complementarities. Journal of Evolutionary Economy, vol. 28, pp. 1053-1080. Available at: https://doi.org/10.1007/s00191-0180600-6, accessed 07.11.2020.

Federer L., Foster E.D., Glusker A., Henderson M., Read K., Zhao S. (2020) The medical library association data services competency: A framework for data science and open science skills development. Journal of the Medical Library Association, vol. 108, no 2, pp. 304-309. DOI: 10.5195/jmla.2020.909.

Feller J., Finnegan P., Nilsson O. (2011) Open innovation and public administration: Transformational typologies and business model impacts. European Journal of Information Systems, vol. 20, no 3, pp. 358-374. Available at: https://doi.org/10.1057/ ejis.2010.65, accessed 07.11.2020.

Fletcher M.A., Zuber-Skerritt O., Bartlett B., Albertyn R., Kearney J. (2010) Meta-Action Research on a Leadership Development Program: A Process Model for Life-long Learning. Systemic Practice and Action Research, vol. 23, no 6, pp. $487-507$. Available at: https://doi.org/10.1007/s11213-010-9173-5, accessed 07.11.2020.

Freitas R.K.V., Dacorso A.L.R. (2014) Inovacao aberta na gestao publica: Analise do plano de acao brasileiro para a Open Government Partnership. Revista de Administracao Publica, vol. 48, no 4, pp. 869-888. Available at: http://dx.doi. org/10.1590/0034-76121545, accessed 07.11.2020.

Fressoli M., Arza V. (2017) Negotiating Openness in Open Science. An Analysis of Exemplary Cases In Argentina. Revista CTS, vol. 12, no 36, pp. 139-162. Available at: http://www.scielo.org.ar/scielo.php?script=sci_arttext\&pid $=$ S1850-00132017000300007, accessed 07.11.2020.

Friesike S., Widenmayer B., Gassmann O., Schildhauer T. (2015) Opening science: Towards an agenda of open science in academia and industry. Journal of Technology Transfer, vol. 40, no 4, pp. 581-601. . Available at: https://doi.org/10.1007/ s10961-014-9375-6, accessed 07.11.2020.

Garcia-Penalvo F.J., Garcia de Figuerola C., Merlo J.A. (2010) Open knowledge: Challenges and facts. Online Information Review, vol. 34, no 4, pp. 520-539. Available at: https://doi.org/10.1108/14684521011072963, accessed 07.11.2020.

Gerhart B., Wright P.M., McMahan G.C., Snell S.A. (2000) Measurement error in research on human resources and firm performance: How much error is there and how does it influence effect size estimates? Personnel Psychology, vol. 53, no 4, pp. 803-834. Available at: https://doi.org/10.1111/j.1744-6570.2000.tb02418.x, accessed 07.11.2020.

Gold E.R. (2016) Accelerating Translational Research through Open Science: The NeuroExperiment. PLoS Biology, vol. 14, no 12, art. e2001259. DOI: 10.1371/journal.pbio.2001259.

Griffin A., Noble C.H., Durmusoglu S.S. (2014) Open Innovation: New Product Development Essentials from the PDMA, Hoboken, NJ: Wiley.

Grimsdottir E., Edvardsson I.R. (2018) Knowledge Management, Knowledge Creation, and Open Innovation in Icelandic SMEs. SAGE Open, vol. 8, no 4. Available at: https://doi.org/10.1177/2158244018807320, accessed 07.11.2020.

Guichard R., Tran S. (2006) L'innovation distribuee: Un modele organisationnel generalisable? Revue Internationale des PME, vol. 19, pp. 79-99. Available at: https://hal.archives-ouvertes.fr/hal-00293630, accessed 07.11.2020.

Gulbrandsen M., Smeby J.-C. (2005) Industry funding and university professors' research performance. Research Policy, vol. 34, no 6, pp. 932-950. Available at: https://doi.org/10.1016/j.respol.2005.05.004, accessed 07.11.2020.

Gura T. (2013) Citizen science: Amateur experts. Nature, no 496 (7444), pp. 259-261. DOI:10.1038/nj7444-259a.

Hagedoorn J., Zobel A.-K. (2015) The role of contracts and intellectual property rights in open innovation. Technology Analysis and Strategic Management, vol. 27, no 9, pp. 1050-1067. Available at: https://doi.org/10.1080/09537325.2015.1056134, accessed 07.11.2020.

Harison E., Koski H. (2010) Applying open innovation in business strategies: Evidence from Finnish software firms. Research Policy, vol. 39, no 3, pp. 351-359. Available at: https://doi.org/10.1016/j.respol.2010.01.008, accessed 07.11.2020.

Henttonen K., Lehtimaki H. (2017) Open innovation in SMEs: Collaboration modes and strategies for commercialization in technology-intensive companies in forestry industry. European Journal of Innovation Management, vol. 20, no 2, pp. 329-347. Available at: https://doi.org/10.1108/EJIM-06-2015-0047, accessed 07.11.2020.

Iglesias-Sanchez P.P., Correia M.B., Jambrino-Maldonado C. (2019) Challenges of Open Innovation in the Tourism Sector. Tourism Planning and Development, vol. 16, no 1, pp. 22-42. Available at: https://doi.org/10.1080/21568316.2017.1393773 , accessed 07.11.2020.

Jamett I., Alvarado L., Maturana S. (2017) Analysis of the state of the art of open innovation: Practical implications in engineering. Revista Ingenieria de Construccion, vol. 32, no 2, pp. 73-84. Available at: https://doi.org/10.4067/S071850732017000200006, accessed 07.11.2020.

Jugend D., de Camargo Fiorini P., Armellini F., Gabriela Ferraria A. (2020) Public support for innovation: A systematic review of the literature andimplications for open innovation. Technological Forecasting and Social Change, vol. 156, art. 119985. Available at: https://doi.org/10.1016/j.techfore.2020.119985, accessed 07.11.2020.

Kafouros M.I., Forsans N. (2012) The role of open innovation in emerging economies: Do companies profit from the scientific knowledge of others? Journal of World Business, vol. 47, no 3, pp. 362-370. Available at: https://doi.org/10.1016/j. jwb.2011.05.004, accessed 07.11.2020.

Katsikis N., Lang A., Debreczeny C. (2016) Evaluation of Open Innovation in B2B from a Company Culture Perspective. Journal of Technology Management and Innovation, vol. 11, no 3, pp. 94-100. Available at: https://doi.org/10.4067/S071827242016000300011, accessed 07.11.2020. 
Khumalo M., Van der Lingen E. (2017) The open business model in a dynamic business environment: A literature review. South African Journal of Industrial Engineering, vol. 28, no 3, pp. 147-160. Available at: https://doi.org/10.7166/28-3-1851, accessed 07.11.2020.

Krause W., Schutte C. (2015) A perspective on Open Innovation in Small and medium-sized enterprises in South Africa, and Design Requirements for an Open Innovation Approach. The South African Journal of Industrial Engineering, vol. 26, no 1, pp. 163-178. Available at: https://doi.org/10.7166/26-1-997, accessed 07.11.2020.

Lakeman-Fraser P., Gosling L., Moffat A.J., West S.E., Fradera R., Davies L., Ayamba M.A., Ayamba, M.A., van der Wal R. (2016) To have your citizen science cake and eat it? Delivering research and outreach through Open Air Laboratories (OPAL). BMC Ecology, vol. 16, art. 16. Available at: https://doi.org/10.1186/s12898-016-0065-0, accessed 07.11.2020.

Lee G., Benoit-Bryan J., Johnson T.P. (2012) Survey research in public administration: Assessing mainstream journals with a total survey error framework. Public Administration Review, vol. 72, no 1, pp. 87-97. Available at: https://doi.org/10.1111/ j.1540-6210.2011.02482.x, accessed 07.11.2020.

Lehtimaki T., Simula H., Salo J. (2009) Applying knowledge management to project marketing in a demanding technology transfer project: Convincing the industrial customer over the knowledge gap. Industrial Marketing Management, vol. 38, no 2, pp. 228-236. Available at: https://doi.org/10.1016/j.indmarman.2008.12.008, accessed 07.11.2020.

Lewis N.A. (2020) Open Communication Science: A Primer on Why and Some Recommendations for How. Communication Methods and Measures, vol. 14, no 2, pp. 71-82. Available at: https://doi.org/10.1080/19312458.2019.1685660, accessed 07.11.2020.

Lichtenthaler U. (2010) Intellectual property and open innovation: An empirical analysis. International Journal of Technology Management, vol. 52, no 3-4, pp. 372-391. DOI: 10.1504/IJTM.2010.035981.

Liu M., Hull C.E., Hung Y.-T.C. (2017) Starting open source collaborative innovation: the antecedents of network formation in community source. Information Systems Journal, vol. 27, no 5, pp. 643-670. . Available at: https://doi.org/10.1111/isj.12113, accessed 07.11.2020.

Lopes A., Ferrarese A., Carvalho M.M. (2017) Inovacao aberta no processo de pesquisa e desenvolvimento: uma analise da cooperacao entre empresas automotivas e universidades. Gestao e Producao, vol. 24, pp. 653-666. Available at: https://doi. org/10.1590/0104-530x2138-16, accessed 07.11.2020.

Lucia O., Burdio J.M., Acero J., Barragan L.A., Garcia J.R. (2012) Educational opportunities based on the university-industry synergies in an open innovation framework. European Journal of Engineering Education, vol. 37, no 1, pp. 15-28. Available at: https://doi.org/10.1080/03043797.2011.644762, accessed 07.11.2020.

Martinez-Noya A., Narula R. (2018) What more can we learn from R\&D alliances? A review and research agenda. Business Research Quarterly, vol. 21, pp. 195-212. Available at: https://doi.org/10.1016/j.brq.2018.04.001, accessed 07.11.2020.

Merino E.A.D. Forcellini F.A., Ariente Neto R., Wagner A.(2018) Modelo para avaliar o comportamento dinamico daevolucao da comercializacao de produtos em umcontexto de inovacao aberta. Gestao e Producao, vol. 25, no 3, pp. 645-657. Available at: http://dx.doi.org/10.1590/0104-530X1594-14, accessed 07.11.2020.

Morandi V. (2013) The management of industry-university joint research projects: How do partners coordinate and control R\&D activities? Journal of Technology Transfer, vol. 38, no 2, pp. 69-92. Available at: https://doi.org/10.1007/s10961-0119228-5, accessed 07.11.2020.

Nambisan S., Lyytinen K., Majchrzak A., Song M. (2017) Digital Innovation Management: Reinventing Innovation Management Research in a Digital World. MIS Quarterly, vol. 41, no 1, art. 03. DOI: 10.25300/MISQ/2017/41:1.03.

Neely A., Gregory M., Platts K. (2005) Performance measurement system design: A literature review and research agenda. International Journal of Operations and Production Management, vol. 15, no 4, pp. 80-116. Available at: https://doi. org/10.1108/01443579510083622, accessed 07.11.2020.

Ngongoni C.N., Grobbelaar S., Schutte C. (2017) The role of open innovation intermediaries in entrepreneurial ecosystems design. South African Journal of Industrial Engineering, vol. 28, no 3, pp. 56-65. Available at: https://doi.org/10.7166/28-31839, accessed 07.11.2020.

Ottonicar S.L.C., Nascimento N.M., Mosconi E. (2018) Information Literacy and digital disruption in Industry 4.0. XIX Encontro de Pesquisadores: Pesquisa Cientifica e Desenvolvimento, Franca (Sao Paulo): Programa de Pos-Graduacao em Desenvolvimento Regional (UniFAcef), pp. 631-638. Available at: https://www.researchgate.net/publication/328368535_INFORMATION_LITERACY_AND_DIGITAL_DISRUPTION_IN_INDUSTRY_40, accessed 07.11.2020.

Perkmann M., Walsh K. (2007) University-industry relationships and open innovation: Towards a research agenda. International Journal of Management Reviews, vol. 9, no 4, pp. 259-280. Available at: https://doi.org/10.1111/j.1468-2370.2007.00225.x, accessed 07.11.2020.

Piedra N., Suarez J.P. (2018) Hacia la Interoperabilidad Semantica para el Manejo Inteligente y Sostenible de Territorios de Alta Biodiversidad usando SmartLand-LD. RISTI - Revista Iberica de Sistemas e Tecnologias de Informacao, vol. 26, pp. 104-121. Available at: https://doi.org/10.17013/risti.26.104-121, accessed 07.11.2020.

Pitassi C. A. (2012) Virtualidade nas estrategias de inovacao aberta: proposta dearticulacao conceitual. Revista de Administracao Publica, vol. 46, no 2, pp. 619-641. Available at: https://doi.org/10.1590/S0034-76122012000200013, accessed 07.11.2020.

Ramirez-Montoya M. S., Garcia-Penalvo F.-J. (2018) Co-creation and open innovation: Systematic literature review. Comunicar, vol. 26, no 54, pp. 09-18. Available at: https://doi.org/10.3916/C54-2018-0, accessed 07.11.2020.

Remneland-Wikhamn B. (2013) Two different perspectives on open innovation - Libre versus contro. Creativity and Innovation Management, vol. 22, no 4, pp. 375-389. Available at: https://doi.org/10.1111/caim.12035, accessed 07.11.2020.

Riley J.M., Klein R., Miller J., Sridharan V. (2016) How internal integration, information sharing, and training affect supply chain risk management capabilities. International Journal of Physical Distribution and Logistics Management, vol. 46, no 10, pp. 953-980. DOI:10.1108/IJPDLM-10-2015-0246. 
Rodrigues L.C., Maccari E.A., Campanario M.A. (2010). Expanding the Open Innovation Convept: The case of TOTVS S.A. Journal of Information Systems and Technology Management, vol. 7, no 3, pp. 737-754. DOI: 10.4301/S180717752010000300011.

Roman M., Liu J., Nyberg T. (2018) Advancing the open science movement through sustainable business model development. Industry and Higher Education, vol. 32, no 4, pp. 226-234. Available at: https://doi.org/10.1177/0950422218777913, accessed 07.11.2020.

Rubera G., Chandrasekaran D., Ordanini A. (2016) Open innovation, product portfolio innovativeness and firm performance: the dual role of new product development capabilities. Journal of the Academy of Marketing Science, vol. 44, pp. 166-184. Available at: https://doi.org/10.1007/s11747-014-0423-4, accessed 07.11.2020.

Sa C., Grieco J. (2016) Open Data for Science, Policy, and the Public Good. Review of Policy Research, vol. 33, no 5, pp. 526543. Available at: https://doi.org/10.1111/ropr.12188, accessed 07.11.2020.

Saebi T., Foss N.J. (2015) Business models for open innovation: Matching heterogeneous open innovation strategies with business model dimensions. European Management Journal, vol. 33, no 3, pp. 201-213. Available at: https://doi.org/10.1016/j. emj.2014.11.002, accessed 07.11.2020.

Sanchez-Gonzalez G., Herrera L. (2014) Effects of customer cooperation on knowledge generation activities and innovation results of firms. Business Research Quarterly, vol. 17, pp. 292-302. Available at: https://doi.org/10.1016/j.brq.2013.11.002, accessed 07.11.2020.

Schenk E., Guittard C. (2012) Une typologie des pratiques de Crowdsourcing: l'externalisation vers la foule, au-dela du processus d'innovation. Management International, vol. 16, pp. 89-100. Available at: https://doi.org/10.7202/1012395ar , accessed 07.11.2020.

Schlagwein D., Conboy K., Feller J., Leimeister J.M., Morgan L. (2017) “Openness” with and without Information Technology: A Framework and a Brief History. Journal of Information Technology, vol. 32, pp. 297-305. Available at: https://doi. org/10.1057/s41265-017-0049-3, accessed 07.11.2020.

Schuster G., Brem A. (2015) How to benefit from open innovation? An empirical investigation of open innovation, external partnerships and firm capabilities in the automotive industry. International Journal of Technology Management, vol. 69, no 1, pp. 54-76. DOI: 10.1504/IJTM.2015.071031

Schwab K. (2016) The fourth industrial revolution, New York: Crown Business.

Scuotto V., Beatrice O., Valentina C., Nicotra V., Di Gioia L., Farina Briamonte M. (2020) Uncovering the micro-foundations of knowledge sharing in open innovation partnerships: An intention-based perspective of technology transfer. Technological Forecasting and Social Change, vol. 152, art. 119906. Available at: https://doi.org/10.1016/j.techfore.2019.119906, accessed 07.11.2020.

Secundo G., Toma A., Schiuma G., Passiante G. (2019) Knowledge transfer in open innovation: A classification framework for healthcare ecosystems. Business Process Management Journal, vol. 25, no 1, pp. 144-163. Available at: https://doi. org/10.1108/BPMJ-06-2017-0173, accessed 07.11.2020.

Serrano-Bedia A.M., Lopez-Fernandez M.C., Garcia-Piqueres G., Sharratt J., McMurdo A. (2018) Complementarity between innovation knowledge sources: Does the innovation performance measure matter? Business Research Quarterly, vol. 21, no 1, pp. 53-67. Available at: https://doi.org/10.1016/j.brq.2017.09.001, accessed 07.11.2020.

Simeth M., Raffo J.D. (2013) What makes companies pursue an Open Science strategy? Research Policy, vol. 42, pp. $1531-1543$. Available at: https://doi.org/10.1016/j.respol.2013.05.007, accessed 07.11.2020.

Smith M.L., Seward R. (2017) Openness as social praxis. First Monday, vol. 22, no 4, art. 7073. Available at: https://doi. org/10.5210/fm.v22i4.7073, accessed 07.11.2020

Stodden V. (2010) Open science: Policy implications for the evolving phenomenon of user-led scientific innovation. Journal of Science Communication, vol. 9, no 1, art. 05. Available at: https://doi.org/10.22323/2.09010205, accessed 07.11.2020.

Strasak A.M., Zaman Q., Pfeiffer K.P., Göbel G., Ulmer H. (2007) Statistical errors in medical research - A review of common pitfalls. Swiss Medical Weekly, vol. 137, no 3-4, pp. 44-49. Available at: https://pubmed.ncbi.nlm.nih.gov/17299669/, accessed 07.11.2020.

Touati N., Denis J. (2013) Analyse critique de la litterature scientifique portant sur l'innovation dans le secteur public: Bilan et perspectives de recherche prometteuses. Telescope: Revue d'analyse comparee en administration publique, vol. 19, no 2, pp. 1-21. Available at: https://doi.org/10.7202/1023837ar, accessed 07.11.2020.

Tranfield D., Denyer D., Smart P. (2003) Towards a Methodology for Developing Evidence-Informed Management Knowledge by Means of Systematic Review. British Journal of Management, vol. 14, pp. 207-222. Available at: https://doi. org/10.1111/1467-8551.00375, accessed 07.11.2020.

Valencia-Vazquez R., Perez-Lopez M.E., Vicencio-De-La-Rosa M.G., Martinez-Prado M.A., Rubio-Hernandez R. (2014) Knowledge and technology transfer to improve the municipal solid waste management system of Durango City, Mexico. Waste Management and Research, vol. 32, no 9, pp. 848-856. Available at: https://doi.org/10.1177\%2F0734242X14546035, accessed 07.11.2020.

Vercueil J. (2012) Les pays emergents. Bresil - Russie - Inde - Chine... Mutations economiques et nouveaux defies (3rd ed.), Paris: Breal.

Vicente-Saez R., Martinez-Fuentes C. (2018) Open Science now: A systematic literature review for an integrated definition. Journal of Business Research, vol. 88, pp. 428-436. https://doi.org/10.1016/j.jbusres.2017.12.043, accessed 07.11.2020.

Viseur R. (2015) Open Science - Practical Issues in Open Research Data. Proceedings of 4th International Conference on Data Management Technologies and Applications (DATA-2015), Colmar (France) SCITEPRESS - Science and Technology Publications, pp. 201-206. Available at: https://doi.org/10.5220/0005558802010206, accessed 07.11.2020. 
Vlaisavljevic V., Medina C.C., Van Looy B. (2020) The role of policies and the contribution of cluster agency in the development of biotech open innovation ecosystem. Technological Forecasting and Social Change, vol. 155, art. 119987. Available at: https://doi.org/10.1016/j.techfore.2020.119987, accessed 07.11.2020.

Vrgovic P., Vidicki P., Glassman B., Walton A. (2012) Open innovation for SMEs in developing countries - An intermediated communication network model for collaboration beyond obstacles. Innovation: Management, Policy and Practice, vol. 14, no 3, pp. 290-302. Available at: https://doi.org/10.5172/impp.2012.14.3.290, accessed 07.11.2020.

Watson M. (2015) When will 'open science' become simply 'science'? Genome Biology, vol. 16, art. 101. Available at: https://doi. org/10.1186/s13059-015-0669-2, accessed 07.11.2020.

West J., Gallaguer S. (2006) Patterns of Open Innovation in Open Source Software // Open Innovation: Researching a New Paradigm (eds. H. Chesbrough, W.Vanhaverbeke, J. West), Oxford: Oxford University Press, pp. 82-106.

Wu I.-L., Hu Y.-P. (2018) Open innovation based knowledge management implementation: A mediating role of knowledge management design. Journal of Knowledge Management, vol. 22, no 8, pp. 1736-1756. Available at: https://doi.org/10.1108/ JKM-06-2016-0238, accessed 07.11.2020.

Yoon D. (2017) The information science policy for the public open data of the national research institute. Cogent Business and Management, vol. 4, no 1, art. 1406321. DOI: 10.1080/23311975.2017.1406321.

Yun J.J., Yang J., Park K. (2016) Open Innovation to Business Model: New Perspective to Connect between Technology and Market. Science, Technology and Society, vol. 21, no 3, pp. 324-348. Available at: https://doi.org/10.1177\%2F0971721816661784, accessed 07.11.2020. 